\title{
Distribusi Subtipe Juvenile Idiopathic Arthritis di Bandung
}

\author{
Reni Ghrahani, Budi Setiabudiawan, Gartika Sapartini, Hesti Puspasari \\ Departemen Ilmu Kesehatan Anak \\ Fakultas Kedokteran Universitas Padjadjaran-RS Dr. Hasan Sadikin Bandung
}

\begin{abstract}
Abstrak
Juvenile idiopathic arthritis (JIA) merupakan penyakit reumatik kronik tersering pada anak yang terjadi sebelum usia 16 tahun. Penelitian ini bertujuan mengevaluasi profil penderita yang didiagnosis JIA. Dilakukan penelitian deskriptif retrospektif terhadap penderita JIA yang datang ke Divisi Alergi Imunologi Departemen Ilmu Kesehatan Anak Rumah Sakit Dr. Hasan Sadikin Bandung pada periode Januari 2006-Oktober 2011 berdasarkan rekam medis. Didapatkan 28 penderita JIA terdiri atas 10 anak laki-laki dan 18 anak perempuan, dengan rentang usia 2-14 tahun, usia rata-rata 8,25 $\pm 3,62$ tahun. Sebanyak 14 penderita JIA merupakan tipe oligoartritis persisten, 6 tipe sistemik, 5 tipe poliartritis, dan terdapat 1 orang penderita poliartritis tipe dewasa. Pada pemeriksaan laboratorium, didapatkan 2 penderita dengan faktor reumatoid positif dan 14 penderita negatif. Terapi yang diberikan obat antiinflamasi nonsteroid sebagai protokol terapi standar, steroid, dan disease modifying anti-rheumatic drugs (metotreksat). Terdapat 3 penderita meninggal yang semuanya merupakan tipe sistemik. Simpulan, sebagian besar JIA merupakan tipe oligoartritis persisten, lebih banyak ditemukan pada anak perempuan dibandingkan dengan laki-laki. Kasus kematian terjadi pada JIA tipe sistemik. Sebagian besar penderita memberikan respons yang baik terhadap protokol terapi standar. [MKB. 2012;44(2):101-5].
\end{abstract}

Kata kunci: Anak, juvenile idiopathic arthritis, subtipe

\section{Distribution of Juvenile Idiophatic Arthritis Subtypes in Bandung}

\begin{abstract}
Juvenile idiopathic arthritis (JIA) is the most common chronic rheumatic disease in children which begin before 16 years of age. The objective of this study was to evaluate the profile of patients who diagnosed as JIA. The descriptive retrospective study was done to patients with JIA who came to Allergy Immunology Division, Department of Child Health Dr. Hasan Sadikin Hospital Bandung during January 2006-October 2011 period, based on the medical records. There were 28 patients with JIA consisted of 10 boys and 18 girls, age ranged 2-14 years, with mean age of onset of $8.25 \pm 3.62$ years. There were 14 patients with persistent oligoarthritis type, 6 patients with systemic type, 5 patients with polyarthritis type and 1 patient with polyarthritis adult type. The laboratory data showed 2 patients with positive rheumatoid factor and 14 patients were negative. Non-steroidal anti-inflammatory drugs as standard protocol therapy, steroids and disease modifying anti-rheumatic drugs (methotrexate) were used for treatment. There were 3 patients with systemic type death. In conclusions, most of JIA cases were persistent oligoathritis type, girls more than boys, and all death cases were systemic JIA. Most of cases had satisfactory therapeutic outcomes with standard protocol therapy. [MKB. 2012;44(2):101-5].
\end{abstract}

Key words: Children, juvenile idiopathic arthritis, subtypes

Korespondensi: Reni Ghrahani, dr., Sp.A, Departemen Ilmu Kesehatan Anak Fakultas Kedokteran Universitas PadjadjaranRumah Sakit Dr. Hasan Sadikin Bandung, jalan Pasteur 38 Bandung, mobile 08122111482, e-mail renighrahani@yahoo.com 


\section{Pendahuluan}

Juvenile idiopathic arthritis (JA) merupakan artritis persisten yang menetap lebih dari 6 minggu dengan onset usia kurang dari 16 tahun, setelah penyebab lain artritis disingkirkan. ${ }^{1-3}$ Istilah JIA merupakan istilah baru yang dikembangkan oleh International League of Associations for Rheumatology (ILAR) untuk mendiagnosis artritis kronik pada anakanak, menggantikan istilah juvenile rheumatoid arthritis (JRA). ${ }^{1-6}$ Penyakit ini merupakan penyakit aktif yang dapat terus berlangsung sampai usia dewasa dengan akibat berpotensi menyebabkan keterbatasan fungsional dan menurunkan kualitas hidup seseorang. ${ }^{1-6}$ Sampai saat ini penyebab JIA belum diketahui, namun bukti-bukti yang ada menunjukkan pengaruh faktor genetik dan respons autoimun abnormal sehingga terjadi inflamasi dan destruksi sendi yang progresif.?

Artritis kronik pada anak bukan merupakan penyakit yang jarang, tetapi frekuensi sesungguhnya pada kejadian penyakit ini tidak diketahui. Insidensi dan prevalensinya di seluruh dunia bervariasi bergantung pada ras, kerentanan imunogenetik, dan lingkungan. ${ }^{3,8}$ Data dari dua Rumah Sakit pusat di Inggris terdapat insidensi 10 per 100.000 populasi di bawah usia 16 tahun dan diperkirakan 1.000 kasus baru setiap tahunnya. Distribusi subtipe kasus tersebut tidak diketahui. ${ }^{3}$

Data lain menyatakan insidensi artritis kronik bervariasi 2-20/100.000 populasi. Sebuah survei di Michigan tahun 1960-1970 mencatat minimal insidensi 9,2/100.000 anak per tahun. Estimasi di Finlandia 6-8/100.000, di Norwegia insidensi 22,6/100.000, sebanyak 42\% dengan alel human leukocyte antigen $\mathrm{B} 27$ positif. 8

Beberapa penelitian di negara berkembang melaporkan prevalensi JIA bervariasi antara 16 dan 150/100.000 populasi, namun pada sebuah ulasan dinyatakan angka prevalensi tersebut terlalu rendah. Survei berbasis komunitas di Australia melaporkan bahwa prevalensi JIA berdasarkan pemeriksaan klinis yang dilakukan oleh ahli reumatologi pada anak usia sekolah sebanyak 400 $/ 100.000$ populasi. $^{2}$

Di Indonesia belum ada data yang menunjukkan besarnya morbiditas penyakit ini, sehingga tujuan penelitian ini untuk mengevaluasi profil penderita yang didiagnosis JIA.

\section{Metode}

Penelitian ini merupakan penelitian deskriptif retrospektif terhadap penderita yang tercatat dalam register Divisi Alergi dan Imunologi Departemen Ilmu Kesehatan Anak-Rumah Sakit Dr. Hasan Sadikin Bandung dan didiagnosis JIA. Definisi artritis harus memenuhi kriteria bengkak pada sendi atau terdapat $\geq 2$ keadaan sebagai berikut: nyeri, hangat, dan gerak yang terbatas. Penyebab artritis lain harus terlebih dahulu disingkirkan sebelum mendiagnosis JIA, antara lain penyakit infeksi (misal artritis septik), noninfeksi (misal demam reumatik akut), penyakit hematologi dan keganasan (misal hemofilia dan leukemia), vaskulitis (Henoch Scholein purpura), dan penyakit autoimun lainnya (systemic lupus erythematosus). ${ }^{1}$ Juvenile idiopathic arthritis diklasifikasi menjadi 6 subtipe yaitu sistemik, oligoartritis, poliartritis, enthesitis-related arthritis, psoriatic arthritis, dan undifferentiated arthritis. ${ }^{1-5,9}$

Data diambil dari rekam medis, baik rawat jalan maupun rawat inap periode Januari 2006Oktober 2011. Data yang diambil anak berusia $<16$ tahun dan dikumpulkan data mengenai usia, jenis kelamin, usia saat pertama kali didiagnosis JIA, dan klasifikasi penyakitnya. Semua gejala klinis dan keluhan utama yang timbul dicatat dan dikelompokkan. Gejala klinis utama yaitu artritis dan febris. Pemeriksaan penunjang yang dicatat berupa tes anti nuclear antibody (ANA) dan faktor reumatoid.

Data ditampilkan dalam bentuk mean dan standar deviasi (mean \pm SD) serta frekuensi distribusi kasus.

\section{Hasil}

Pada penelitian didapatkan 28 anak yang didiagnosis JIA. Usia penderita bervariasi mulai dari 2 hingga 14 tahun dengan usia rata-rata saat pertama kali ditegakkan diagnosis 8,25 $\pm 3,62$ tahun. Perempuan lebih banyak dibandingkan dengan laki-laki dengan rasio 1,8:1. Insidensi JIA di RS Dr. Hasan Sadikin tahun 2011 sebesar 1,3/100.000 (Tabel 1).

Sebanyak 23 penderita datang dengan keluhan utama nyeri pada sendi dan 3 penderita datang dengan febris. Pemeriksaan penunjang meliputi tes ANA pada 13 penderita semua didapatkan hasil negatif serta faktor reumatoid positif pada dua penderita (Tabel 2). Tipe oligoartritis persisten didapatkan pada 14 penderita, diikuti tipe sistemik pada 6 penderita. Didapatkan 1 penderita dengan poliartritis tipe dewasa, namun tidak ada yang masuk sebagai enthesitis related arthritis ataupun undiferentiated arthritis. Tiga penderita meninggal dunia, ketiganya merupakan JIA tipe sistemik (Tabel 3).

Semua penderita mendapat obat antiinflamasi nonsteroid(OAINS) berupaibuprofen, tiga penderita mendapat disease-modifying antirheumatic drugs (DMARDs) terutama metotreksat serta seorang penderita mendapat intra-articular triamsinolon hexaxetonide (IATH). Sebagian besar penderita 
Tabel 1 Karakteristik Penderita Juvenile Idiophatic Arthritis

\begin{tabular}{lc}
\hline \multicolumn{1}{c}{ Karakteristik } & $\mathbf{n = 2 8}$ \\
\hline Rentang usia (tahun) & $2-14$ \\
Rata-rata \pm standar deviasi & $8,25 \pm 3,62$ \\
Jenis kelamin & \\
$\quad$ Laki-laki & 10 \\
$\quad$ Perempuan & 18 \\
Rasio perempuan : laki-laki & $1,8: 1$ \\
\hline
\end{tabular}

memberikan respons yang baik terhadap terapi.

\section{Pembahasan}

Diagnosis JIA ditegakkan cukup sulit oleh karena tidak ada pemeriksaan penunjang spesifik, manifestasi klinis bervariasi, serta gejala yang tumpang tindih dengan berbagai penyakit lain. Keterbatasan penelitian deskriptif retrospektif ini yaitu analisis jumlah penderita yang sedikit. Peneliti melakukan evaluasi riwayat penyakit penderita dan hasil pemeriksaan laboratorium dari rekam medis. Artritis merupakan keluhan utama pada beberapa penyakit autoimun selain JIA, antara lain lupus eritematosus sistemik. ${ }^{10}$

Pada penelitian ini sebagian besar kasus JIA tipe oligoartritis, kasus tipe sistemik pada urutan kedua paling banyak, sedangkan pada penelitian lain didapatkan urutan kedua tipe poliartritis. ${ }^{5}$

Insidensi JIA di RS Dr. Hasan Sadikin tahun 2011 sebesar 1,3/100.000. Insidensi yang rendah dapat disebabkan kesulitan diagnosis, mengingat manifestasi klinis yang bervariasi. Rasio anak perempuan dan laki-laki sebesar 1,8:1; hal ini serupa dengan penelitian lain yang mendapatkan anak perempuan lebih banyak daripada lakilaki. ${ }^{5}$ Pada penelitian ini didapatkan usia ratarata $8,25 \pm 3,62$ tahun, hal ini tidak jauh berbeda
Tabel 2 Gejala Klinis dan Pemeriksaan Penunjang Juvenile Idiophatic Arthritis

\begin{tabular}{lr}
\hline \multicolumn{1}{c}{ Deskripsi } & $\mathbf{n}=\mathbf{2 8}$ \\
\hline Keluhan utama & \\
Febris & 3 \\
Artritis & 23 \\
Artralgia & 2 \\
Pemeriksaan penunjang & \\
Antibodi antinuklear (ANA) & \\
$\quad$ Positif & 0 \\
Negatif & 13 \\
Tidak diperiksa & 15 \\
Faktor reumatoid & \\
$\quad$ Positif & 2 \\
Negatif & 14 \\
Tidak diperiksa & 12 \\
\hline
\end{tabular}

dengan penelitian yang dilakukan oleh Yeh dkk. ${ }^{11}$ di Taiwan yaitu 7,4 $\pm 5,5$ tahun.

Kriteria diagnosis JIA yang digunakan yaitu kriteria revisi ILAR berupa bengkak pada sendi atau terdapat $\geq 2$ keadaan sebagai berikut: nyeri, hangat, dan gerak yang terbatas. Sebelum diagnosis ditegakkan harus disingkirkan penyakit infeksi (artritis septik), noninfeksi (demam reumatik akut), penyakit hematologi dan keganasan (hemofilia, leukemia), vaskulitis (Henoch-Schonlein purpura), atau penyakit autoimun lainnya seperti lupus eritematosus sistemik. Febris dan artritis merupakan keluhan utama yang paling sering didapatkan, pada penelitian ini ditemukan artralgia, artritis, dan febris sebagai gejala yang sering dikeluhkan penderita yang datang ke Rumah Sakit Dr. Hasan Sadikin Bandung. Pada penelitian Yeh dkk. ${ }^{11}$ semua penderita yang diteliti $(\mathrm{n}=16)$ mengalami demam berkepanjangan dan ruam eritema muncul pada

Tabel 3 Klasifikasi dan Outcome Juvenile Idiophatic Arthritis

\begin{tabular}{lcc}
\hline Subtipe JIA & $\mathbf{n}=\mathbf{2 8}$ & Kematian $(\mathbf{n}=\mathbf{6})$ \\
\hline Sistemik & 6 & 3 \\
Oligoartritis extended & 2 & 0 \\
$\quad$ persisten & 14 & 0 \\
Poliartritis & 5 & 0 \\
Enthesitis related arthritis & 1 & 0 \\
Psoriatic arthritis & 0 & 0 \\
$\quad$ Undifferentiated arthritis & 0 & 0 \\
\hline
\end{tabular}


saat puncak demam. Pada penelitian ini demam tidak disertai gejala ruam eritema. Hal ini mungkin disebabkan tidak dikeluhkan atau tidak diketahui oleh orangtua penderita.

Hasil laboratorium yang didapatkan tidak jauh berbeda dibandingkan dengan beberapa penelitian sebelumnya dengan tes ANA dan faktor reumatoid. Semua penderita telah disingkirkan kemungkinan artritis karena penyakit yang lain.

Macrophage activation syndrome (MAS) merupakan komplikasi berat pada penyakit kronik reumatoid, khususnya sistemik JIA. Frekuensi MAS disebutkan dalam satu penelitian retrospektif di unit pediatri reumatologi suatu rumah sakit tersier sekitar $6,7 \% .^{11,12}$ Gejala klinis menunjukkan demam akut, hepatosplenomegali, limfadenopati, perdarahan kulit dan mukosa, pansitopenia, serta gangguan sistem saraf pusat, jantung, dan ginjal. Komplikasi MAS sering kali sulit dikenali, oleh karena manifestasi klinis menyerupai JIA sistemik aktif. Pada penelitian ini terdapat 3 orang penderita JIA tipe sistemik yang meninggal dengan dugaan MAS.

Terapi OAINS masih merupakan terapi lini pertama pada JIA karena bersifat analgetik dan antiinflamasi, namun tidak mengubah perjalanan penyakit maupun mencegah progresivitas penyakit. Pediatric Rheumatology Collaborative Study Group (PRCSG) menyatakan bahwa 65\% penderita JIA berespons terhadap OAINS dalam waktu 1 bulan. Efek samping obat yang paling sering terjadi yaitu gangguan gastrointestinal yang dapat berupa gastritis atau gastroduodenitis, sedangkan yang jarang ditemukan gangguan ginjal, jantung, dan sebagainya. ${ }^{13-15}$ Meskipun obat-obatan DMARDs (terutama metotreksat) terbukti efektif untuk terapi JIA, namun tetap memiliki berbagai kekurangan. Seperti obat imunosupresan dan sitotoksik lainnya, pemberian DMARDs dapat menurunkan daya tahan tubuh, bersifat merusak jaringan normal, bahkan diduga dapat menyebabkan keganasan apabila digunakan dalam jangka lama. ${ }^{16}$ Pada penelitian ini terdapat 3 penderita yang mendapat terapi metotreksat dengan hasil yang baik.

Simpulan, insidensi JIA rendah menyebabkan sulitnya penelitian klinis ataupun epidemiologis pada JIA. Pada penelitian ini sebagian besar JIA merupakan tipe oligoartritis persisten, lebih banyak ditemukan pada anak perempuan dibandingkan dengan laki-laki. Semua kasus kematian terjadi pada JIA tipe sistemik. Sebagian besar penderita memberikan respons yang baik terhadap protokol terapi standar.

\section{Daftar Pustaka}

1. Lovell DJ. Juvenile idiopathic arthritis.
Dalam: Klippel JHSJ, Crofford LJ, White $\mathrm{PH}$, penyunting. Primer on the rheumatic disease. Edisi ke-13. New York: Springer; 2008. hlm. 142-8.

2. Ravelli A, Martini A. Juvenile idiopathic arthritis. Lancet. 2007;369(9563):767-78.

3. Goldmuntz EA, White PH. Juvenile idiopathic arthritis: a review for pediatrician. Pediatr Rev. 2006;27(4):e24-32.

4. Cummins C, Connock M, Fry-Smith A, Burls A. A systematic review of effectiveness and economic evaluation of new drug treatment for juvenile idiopathic arthritis: etanercept. Health Technol Assess. 2002;6(17):1-43.

5. Singh-Grewal D. How to treat juvenile idiophatic arthritis [diunduh 15 November 2011]. Tersedia dari: http://www.australian doctor.com.au. 2010:31-6.

6. Gardner-Medwin J. Current development in juvenile idiopathic arthritis. Rheum Dis Top Rev. 2001;5:1-6.

7. Hashkes PJ, Laxer RM, penyunting. Juvenile idiophatic arthritis: insights in to classification, outcomes and treatment. Proceedings of Annual Scientific Meeting American College of Rheumatology; 2005 November 13-17, 2005; San Diego, California.

8. Cassidy JT, Petty RE. Chronic arthritis in childhood. Dalam: Laxer RM, Lindsley $\mathrm{CB}$, penyunting. Textbook of pediatric rheumatology. Edisi ke-5. Philadelphia: Elsevier; 2005. hlm. 209-16.

9. Petty RE, Southwood TR, Manners P, Baum J, Glass DN, Goldenberg J, dkk. International league of associations for rheumatology classification of juvenile idiopathic arthritis: second revision, Edmonton, 2001. J Rheumatol. 2004;31(2):390-2.

10. Setiabudiawan B, Soepriadi M, Garna H, Hafsah T. Manifestasi klinis penderita lupus eritematosus sistemik yang dirawat di Bagian Ilmu Kesehatan Anak RS dr Hasan Sadikin Bandung. MKB. 2002;34(2):60-7.

11. Yeh TL, Huang FY, Shyur SD, Chen TL, Lee CS, Huang DT. Juvenile idiopathic arthritis presenting with prolonged fever. J Microbiol Immunol Infect. 2010;43(3):169-74.

12. Fall N, Barnes M, Thornton S, Luyrink L, Olson J, Illowite NT, dkk. Gene expression profiling of peripheral blood from patients with untreated new-onset systemic juvenile idiopathic arthritis reveals molecular heterogenity that may predict macrophage activation syndrome. Arthritis Rheum. 2007;56(11):3793-804.

13. Olsen NJ, Stein CM. New drugs for rheumatoid arthritis. $\mathrm{N}$ Engl J Med. 
2004;350(21):2167-79.

14. Beukelman T, Patkar NM, Saag KG, TollesonRinehart S, Cron RQ, Dewitt EM, dkk. 2011 American College of Rheumatology recommendations for the treatment of juvenile idiopathic arthritis: initiation and safety monitoring of therapeutic agents for the treatment of arthritis and systemic features. Arthritis Care Res. 2011;63(4):46582.
15. Hashkes PJ, Laxer RM. Juvenile idiopathic arthritis. Dalam: Klippel JHSJ, Crofford $\mathrm{LJ}$, White $\mathrm{PH}$, penyunting. Primer on the rheumatic disease. Edisi ke-13. New York: Springer; 2008. hlm. 153-4.

16. Ramanan AV, Whitworth P, Baildam EM. Use of methotrexate in juvenile idiopathic arthritis. Arch Dis Child. 2003;88(3):197200. 